\title{
The Potential of Concentrated Solar Power for Remote Mine Sites in the Northern Territory, Australia
}

\author{
M. H. Baig, ${ }^{1}$ D. Surovtseva, ${ }^{2}$ and E. Halawa ${ }^{1}$ \\ ${ }^{1}$ Centre for Renewable Energy, Research Institute for the Environment and Livelihoods (RIEL), Charles Darwin University, \\ Casuarina Campus, Darwin, NT 0909, Australia \\ ${ }^{2}$ School of Engineering and IT (SEIT), Charles Darwin University, Casuarina Campus, Darwin, NT 0909, Australia
}

Correspondence should be addressed to E. Halawa; edward.halawa@cdu.edu.au

Received 29 June 2015; Revised 13 October 2015; Accepted 13 October 2015

Academic Editor: Santanu Bandyopadhyay

Copyright ( 2015 M. H. Baig et al. This is an open access article distributed under the Creative Commons Attribution License, which permits unrestricted use, distribution, and reproduction in any medium, provided the original work is properly cited.

\begin{abstract}
The Northern Territory (NT) is among the regions in Australia and the world with the highest solar radiation intensities. The NT has many mine sites which consume significant amount of fossil fuel with consequent greenhouse gas (GHG) emissions. The environmental concern related to the fossil fuel consumption and availability of immense solar energy resource in the NT open the possibilities for considering the provision of power to the mining sites using proven solar technologies. Concentrating solar power (CSP) systems are deemed as the potential alternatives to current fossil fuel based generating systems in mining industry in the NT. The finding is based on consideration of the major factors in determining the feasibility of CSP system installation, with particular reference to the NT mine sites. These are plant design requirements, climatic, environmental, and other requirements, and capital and operating costs. Based on these factors, four mine sites have been identified as having the potential for CSP plants installation. These are McArthur River Mine, Ranger Mine, Northern Territory Gold Mines, and Tanami Operations. Each site could be served by one CSP plant to cater for the needs of mining operation and the local communities.
\end{abstract}

\section{Introduction}

Like many other nations, Australia is committed to reducing its carbon footprint by reducing its greenhouse gas (GHG) emissions by $20 \%$ by 2020 and an additional target of reducing them to half by 2050 [1]. Australia's annual GHG emissions for the year to December 2012 were estimated to be $551.9 \mathrm{Mt} \mathrm{CO}_{2}$-e [2]. Australia generates only $1.5 \%$ of global GHG emissions; however, for the year to June 2012, the national inventory emissions per capita were about 24.4 tonnes $\mathrm{CO}_{2}$-e [3]. On a per capita basis, Australia is one of the world's highest GHG. Australia's main sources of GHG pollution are electricity generation, transport, agriculture, industrial processes, land use, and waste [4]. Among these sectors, electricity generation is the biggest GHG emitter with a $36 \%$ share [3].

Australia's electricity generation in 2011-2012 is $253,851 \mathrm{GWh}$, a $0.5 \%$ increase from $2010-2011$ [5], with coal (69.1\%) and gas (19.3\%) being the main fuels. The share of all renewable energy sources is $9.4 \%$ with hydro $(5.5 \%)$ and wind power (2.4\%) being the main contributors.

NT's electrical generation can be classified into (1) regulated network and (2) unregulated network which consists of off-grid, pastoral properties, mines, and other. The regulated networks of Alice Springs, Darwin-Katherine, and Tennant Creek [6] generated 1814 GWh in 2010-2011 [7] with a total generating power of $522 \mathrm{MW}$. The unregulated network generated $1600 \mathrm{GWh}$ with total generating capacity of $555 \mathrm{MW}$, of which mining sector generated $430 \mathrm{MW}$ and $1230 \mathrm{GWh}$. These figures show that NT mining sector represents the largest electricity consumer within the unregulated network; on a territory level it also represents significant portion of the overall electricity consumption. In addition mining operations are among NT's biggest consumers of fossil fuels with significant GHG emissions (BREE, 2013). Almost 99\% of the electrical generation in the NT is fuelled by gas [8]. 
The NT is among the regions with richest solar energy resources in the world. The NT has an immense amount of solar energy throughout the year which remains largely untapped. To date, less than $1 \%$ of the Territory's electrical energy generation (and consumption) comes from renewable source $[6,8]$.

With the above background, this paper explores the potential of CSP technology in supplying energy to the mining industry in the NT. NT has abundant solar energy resource and there have been success stories of the CSP technology in a similar environment elsewhere in the world which can be useful in realising this potential in the NT. There has been a recent initiative by the Australian Renewable Energy Agency (ARENA) to provide funding to deployment of solar PV systems to provide power to mining sites (e.g., [9]). An earlier initiative from the same agency has seen the allocation of significant funding "to deliver the next wave of cost reductions, novel technologies, know-how, publications and patents, and concepts ready for development and commercialisation" of the CSP [10]. It is in the anticipatory spirit of the outcome of that latter that this research was conducted.

\section{CSP Technologies and Prospects}

This section presents an overview of the CSP technologies and their prospects being a precursor to the discussion on the feasibility study of CSP in the NT (Section 3).

2.1. CSP Technologies: An Overview. CSP technologies can be classified into (1) parabolic trough systems, (2) central receiver (tower) systems, (3) linear Fresnel systems, and (4) parabolic dish systems. Table 1 presents a summary of main features of various CSP technologies. This summary is used in this research to aid in selecting the relevant CSP technology under the relevant atmospheric, environmental, and economic conditions in this study. Detailed information on these technologies can be found in $[14,15]$.

As shown in Table 1, each technology listed has its own ranges of capacity, operating temperature, the type of power cycles and heat transfer fluids it can work on, water and land requirements, and so forth. The table also lists the advantages and disadvantages of each technology. All these factors must be taken into account when selecting the most appropriate technology for a particular site with its own environmental factors.

CSP systems, also known as solar thermal power plants (STPPs), are flexible to be hybridized with other renewable and conventional systems such as biodiesel fired boilers, wind, and photovoltaic systems. CSP technology is also capable of providing process heat for industrial applications such as water desalination at coastal freshwater-scarce utilities.

STPPs are capable of providing base load power to areas that have high direct solar insolation at costs similar to fossil fuel power generation but with significant reduction in greenhouse gas (GHG) emissions. In addition, power can be transported from insolation rich regions to insolation poor regions. For example, transportation of power to $3000 \mathrm{~km}$ is possible with only $11.5 \%$ losses using $800 \mathrm{kV}$ direct current transmission technologies [16].
CSP systems are versatile and can be integrated with existing or new fossil fuel based power plants to curb the GHG emissions and to extend plant life to a low-emission energy future [1]. Various CSP systems emit much lower GHG compared to conventional fuels (oil, gas, and coal) and roughly the same as the tidal, wave, and PV systems [17].

In order to ensure uninterrupted power supply necessary for mining operations, the CSP systems have to be supplemented with thermal storage. In addition, such systems are generally installed with fuel power backup capacity offering reliable power production to utilities and grid operators.

\subsection{CSP Prospects}

2.2.1. CSP Deployment Worldwide. The first solar thermal power plant became operative in Egypt in 1912 [18]. CSP is considered a proven technology with CSP plants operating in California from 1984 to 1991 [19]. Due to the steep decline in the prices of fossil fuels the support for CSP (including tax incentives and mandatory power purchase) was withdrawn by the government. CSP market reemerged in 2006 in response to the new government incentives such as feed in tariff in Spain and policies requiring utilities to include renewable power. This led to the construction of new CSP plants, raising the global stocks of CSP plants to nearly $1 \mathrm{GW}$ in 2010 [19]. Since then many other countries have invested in CSP with a projected increase in total capacity of up to $15 \mathrm{GW}$ after the completion of the plants that are currently under construction [19].

According to NREL online database [20], to date 18 countries have constructed (or are constructing) CSP systems. The total installed capacity of all the 77 operational CSP plants is $3478.16 \mathrm{MW}$ as of October 2013 (more than twice the capacity in 2012). Of these, $90 \%$ are parabolic trough systems, 8\% linear Fresnel reflector systems, around 2\% central tower systems, and less than $1 \%$ parabolic dish systems. Leading in terms of installed capacity are Spain (60\%) and US (23\%) while the remaining $17 \%$ is in other countries. Additional 17 GW CSP plants are under construction (20\%) or under feasibility and planning stages with approximately half of these in the USA and another half in Spain and China [21].

2.2.2. CSP Deployment in Australia and the NT. Australia enjoys the position as the world leader in terms of solar resources and is contributing relatively well from a research and development point of view. A $100 \mathrm{~kW}$ CSP system called Step 100 was built in Meekatharra in WA in 19811982 [1]. The system employed an Organic Rankine Cycle (ORC) system and operated for only a short time; hence performance data is limited. A $25 \mathrm{~kW}$ steam engine generator powered by a 14-dish system in White Cliffs in the New South Wales was designed by the Australian National University (ANU) and installation completed in 1981 [22]. In 1998, this system was taken over by Solar Systems Pty Ltd. and converted to CPV receivers. However, later in 2008, despite the dishes remaining in fair condition, company decided to decommission the plant [1].

Another Australia's research success was a solar dish with $500 \mathrm{~m}^{2}$ aperture area designed and built by ANU in 


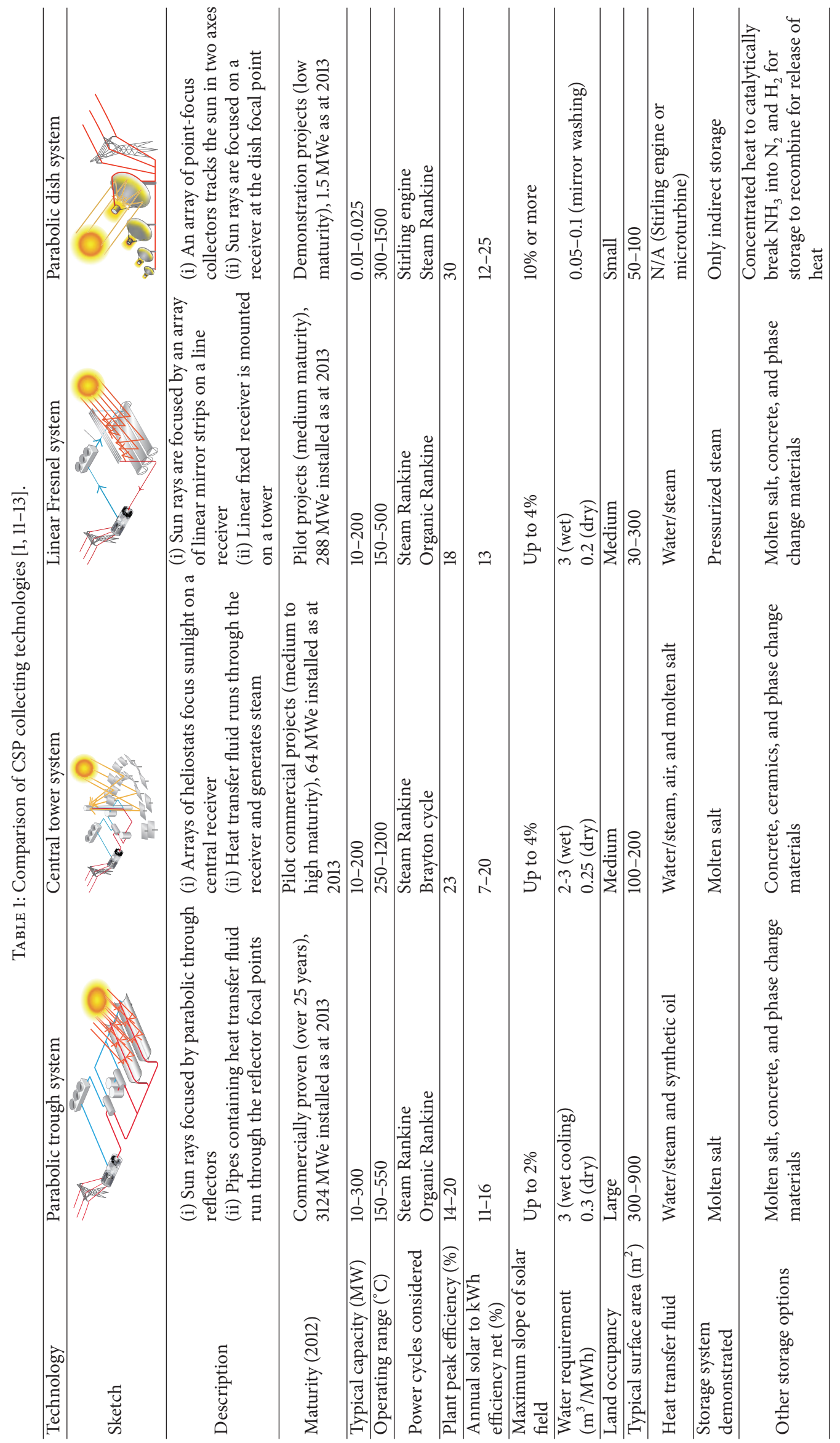




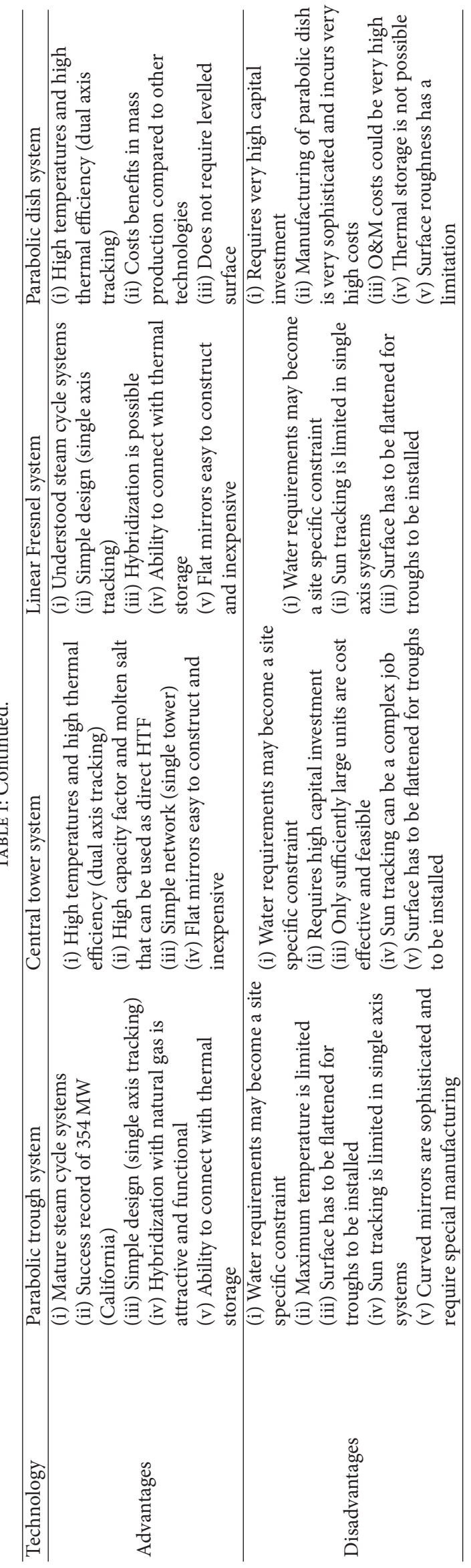


association with a commercial company, Wizard Power. The "Big Dish" was completed in 2009. The National Solar Energy Centre (NSEC) at Newcastle has recently commissioned a central tower plant in collaboration of joint funding by CSIRO. This plant has a $30 \mathrm{~m}$ central tower with 450 heliostats over $4000 \mathrm{~m}^{2}$ collector field for a $500 \mathrm{~kW}$ system [1]. The aim of this research facility is to test solar reforming of natural gas and solar steam generating systems and to investigate solar Brayton cycle systems.

In Australia there are only 5 currently operating CSP systems with a total capacity of $5 \mathrm{MW}$. Few other researchbased CSP projects are also underway [23].

It is estimated that a $10 \mathrm{GW}$ capacity would be able to reduce Australia's emissions by approximately $30 \mathrm{Mt} \mathrm{CO}_{2}$ per year which constitutes $15 \%$ of current electricity sector emissions. In addition, every $100 \mathrm{MW}$ system is expected to create roughly 500 temporary construction related jobs and 20 ongoing operation related jobs. Last but not least, CSP technology offers to preserve precious natural resources which are being exploited for power production. This creates further opportunities for international trade of fossil fuel resources to the parts of the world which are less suitable and/or ready for renewable energy infrastructure. This study predicted that, considering the demand for dispatchable clean energy, CSP market potential would likely strengthen. According to the same study, CSP could provide $30 \%$ of Australia's average total current electricity which is $15 \mathrm{GW}$ [1].

Through ARENA, CSIRO is partnering with 6 universities in Australia, 2 universities in US, and the NREL in the Australian Solar Thermal Research Initiative (ASTRI) with the goal "to lower the cost of solar thermal power to 12 cents a kilowatt hour; targeting 20 cents a kilowatt hour by 2016 and 12 cents by 2020, whilst providing a power source that can be adjusted to demand (dispatchable generation)" [24].

For the NT, the Green Energy Taskforce [6] concluded that "while the costs for solar thermal are still high and the commercial scale is currently too big for the Territory to accommodate, it is approaching a stage where it could be deployed in the NT. It is considered that the best prospects would be in combination with gas generation (to overcome the intermittency)."

Considering the availability of high insolation in NT (see Section 3.2), the potential of STPP is not limited to remote mining sites; surplus power can also be transported locally and internationally, such as to neighboring islands of Indonesia through an intercontinental grid interconnection [25].

\section{Feasibility Parameters of a CSP Plant}

Based on the information presented in Table 1, there are 3 major groups of parameters that need to be considered in assessing the feasibility of a CSP plant installation in a location: (1) plant design requirements including auxiliary services, (2) environmental parameters, and (3) capital and operating costs. This section provides a brief insight into the nature of these parameters and complications associated with them in the context of mining industry in the Northern
Territory, and specific examples are discussed in the following section.

\subsection{CSP Design Requirements}

3.1.1. Optimum Size of CSP Plant and Its Operating Life. One of the main criteria for a CSP plant is the ability to gain sufficient environmental and economic credits over its lifespan. Recommended size of plants varies for different CSP technologies as summarised in Table 1 . Most of the commercial central tower plants built so far are in the range of 10-20 MW whilst the commercial parabolic trough plants in operation are in the range of 30-250 MW. All the commercial CSP plants which are currently in operation have a life between 20 and 35 years. Precise estimation of economically viable size of a CSP plant may require extensive modelling using specific design values for a certain location [26]. As will be discussed in the following section, majority of the operating mines in the Northern Territory would have sufficient power load and lifespan to sustain CSP plant.

3.1.2. Operating Temperatures. Each of the four CSP technologies discussed in Section 2 generates electricity at different operating temperature (Table 1). Higher operating temperature can be achieved with the central tower systems or parabolic dish systems. This temperature can further be used to cater for some of the process requirements, for example, in minerals processing. High temperatures are achieved through the use of heat transfer fluids (e.g., $\left.\mathrm{CO}_{2}\right)$ in integrated solar combined cycle power systems [27]. Most of the on-site ore processing does not involve high temperatures; however in some cases such integrated systems would be required.

3.2. Atmospheric, Environmental, and Other Requirements. According to Masters [28], the most suitable areas for CSP plants include North Africa, the Middle East, Sothern Africa, Australia, and the western side of South America. Rigorous analysis of the conditions in each of these locations reveals that the most crucial factors for CSP plants are the suitable direct normal irradiance (DNI), water availability, land topography, and low risk of extreme weather. Availability of backup power has also to be considered where it is important to ensure uninterrupted operations such as in mines.

The average DNI and the number of days of low DNI (cloudy days) at a location are used in calculating the solar multiple which is required to calculate the mirror area required [29]. In addition, the number of complete cloud cover days at a location is very important in deciding whether a CSP plant is suitable for dispatchable power or only for peak load power and hybridization with other power generating systems [30]. The minimum economically viable value for DNI is between 1800 and $2000 \mathrm{kWh} / \mathrm{m}^{2}$ per year [31, 32].

Figure 1 shows the contour of the average annual solar energy in Australia [33]. As shown, most of the NT regions receive more than $2000 \mathrm{kWh} / \mathrm{m}^{2}$ annually (averaged over 2007-2012 period) with the Central Australia receiving over $2300 \mathrm{kWh} / \mathrm{m}^{2}$. This intensity is considerably higher than that 


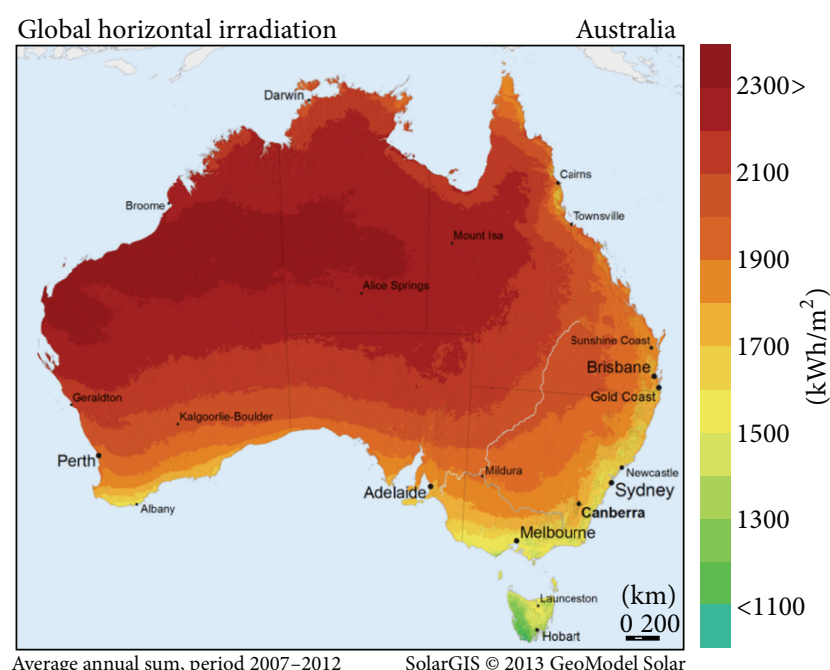

FIGURE 1: Average annual total of solar energy per square meter in Australia [33].
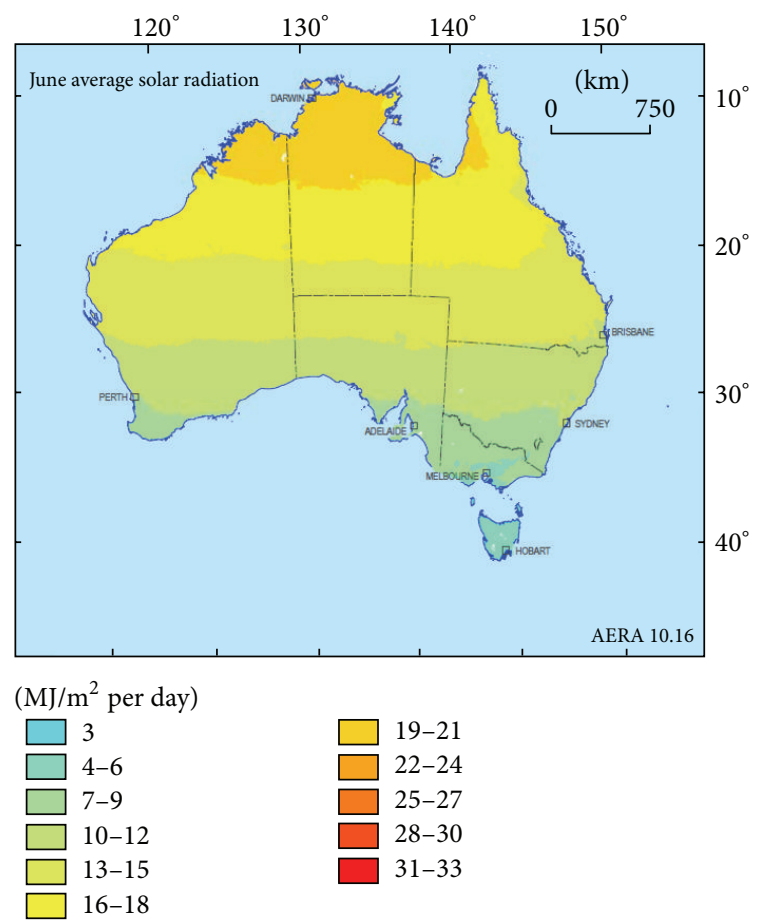

FIgURE 2: Australia's June average solar radiation [34].

of Spain, one of the world's leading countries in solar power technology.

Even during the peak "winter" season in the NT, the mean daily solar radiation ranges from $5.3 \mathrm{kWh} / \mathrm{m}^{2} \cdot \mathrm{d}$ (central region) to $6.7 \mathrm{kWh} / \mathrm{m}^{2} \cdot \mathrm{d}$ (Figure 2).

Since CSP systems rely on the availability of high DNI, it is worth looking at this data for the NT. As seen in Figure 3, which shows Australia's average daily DNI map, the values for the NT range from 22 to $27 \mathrm{MJ} / \mathrm{m}^{2} \cdot \mathrm{d}$.
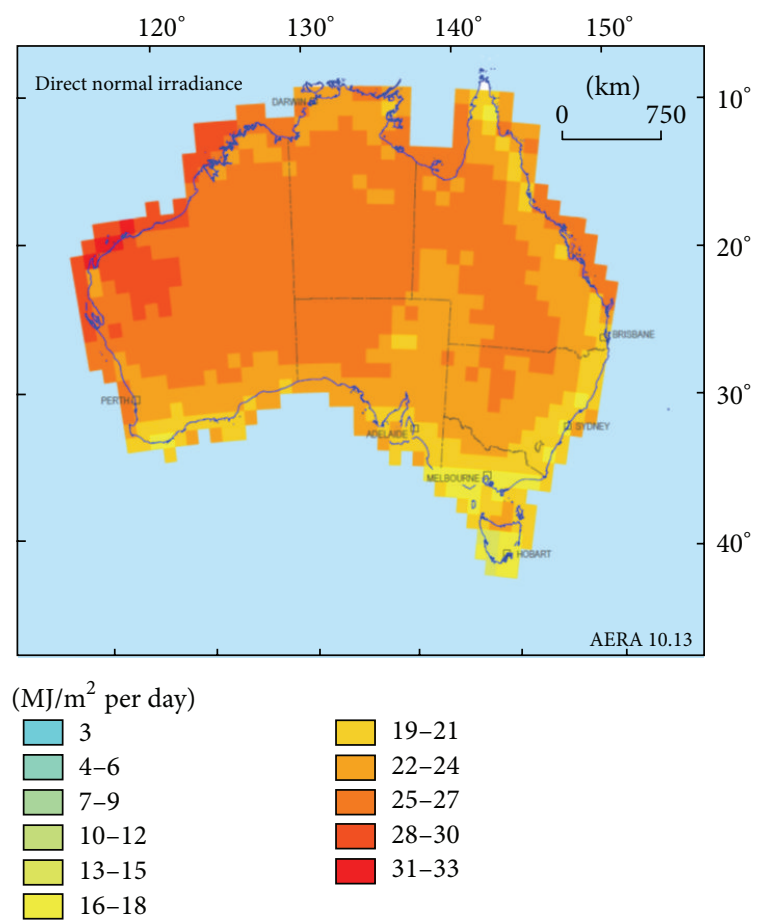

FIgURE 3: Average daily direct normal irradiance in Australia [34].

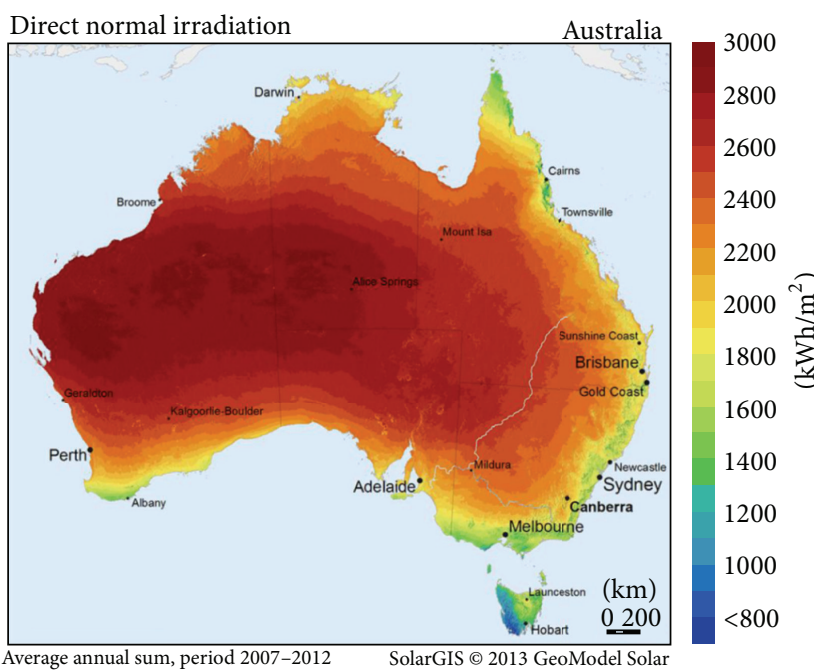

FIGURE 4: Average annual direct normal irradiation in Australia [33].

On an annual basis, the DNI values for the NT range from around $2000 \mathrm{kWh} / \mathrm{m}^{2}$ at the northern coast to around $2800 \mathrm{kWh} / \mathrm{m}^{2}$ at the central region, Figure 4 , which is well above the minimum viable economic value for CSP installation mentioned earlier.

The impact of extreme weather on the CSP design is associated with the construction and building codes that affect the construction costs. NT is one of the parts of the world which is repeatedly affected by tropical cyclones. The extreme tropical cyclones may be seen in an interval of 500 to 1000 years; however less severe cyclones are more 
common [35]. The pattern of wind speed at a location has a direct impact on the capital and ongoing maintenance costs of the collector field of CSP plants. In Solar Energy Generating System (SEGS) plant in USA at least 3000 mirrors are replaced each year which get broken by winds [36]. This information is of utmost importance if a CSP plant is considered in coastal and cyclone prone areas of the NT. The available data for the severity and frequency of cyclones in this region is somewhat scarce [37]. Fortunately, the regions most prone to destructive winds in Australia are well known and most lie within $50-100 \mathrm{~km}$ of the coastline [38]. Majority of the mining operations and thus potential CSP sites lie further inland outside this boundary. Specific locations are discussed in more detail in the following section.

Flooding is another potential environmental hazard which could obstruct accessibility to a power station for routine operations and maintenance and may cause malfunctions in the power systems at a power generation facility. Each potential site would have to be thoroughly investigated for such possibility, and backup power supply would have to be considered.

In CSP plants, water is required for cooling and cleaning purposes. Around $2-3 \mathrm{~m}^{3} / \mathrm{MWh}$ of water is required for various CSP systems $[1,17]$ as summarised in Table 1. Washing water is not required to be of high quality and the discharged/treated waters from elsewhere can be used. In some cases, dry cooling systems may be applicable [29, 39]; however, this may be more expensive and may reduce annual production by $7 \%$ and increase cost of electricity production by $10 \%$ [17]. The majority of CSP plants installed to date are generally in desert environments having water scarcity issues. Therefore, there is increased interest in dry cooling condenser technologies such as MACCSol air cooled condenser technology [40]. The Jemalong Solar Thermal Station $\left(6 \mathrm{MW}_{\text {th }}\right)$ in Australia will be the first in the world to deploy MACCSol air cooled condenser technology [41]. Situation in the NT is similar to most of the mining operations of interest being located in dry inland areas (see Figure 5, Section 4).

The general requirement for land area is 20,000 to $30,000 \mathrm{~m}^{2}$ per MW of electricity produced through parabolic trough systems $[16,17]$. However, large-scale solar power plants require roughly 2 hectares of land per MW of power [23]. The optimum topography and therefore orientation of the solar collector fields can be estimated from the slope limits presented in Table 1. Northern Territory of Australia is characterised by a very stable landscape with minimal slopes in most regions [42]. Thus it is deemed suitable for largescale installations such as CSP plants. Availability of land may be a serious issue due to the strict regulations around the Aboriginal land rights [43]; however it is not unprecedented that such land is developed. In fact, absolute majority of mining tenements are located on Aboriginal land.

3.3. Capital and Operating Costs of CSP. Investment costs are a major factor in determining the size and the economically viable life time of a CSP. For commercial power generation, Hinkley et al. [39] indicated that the cost effective size of CSP tower plants is $50 \mathrm{MW}$ and $150 \mathrm{MW}$ for parabolic

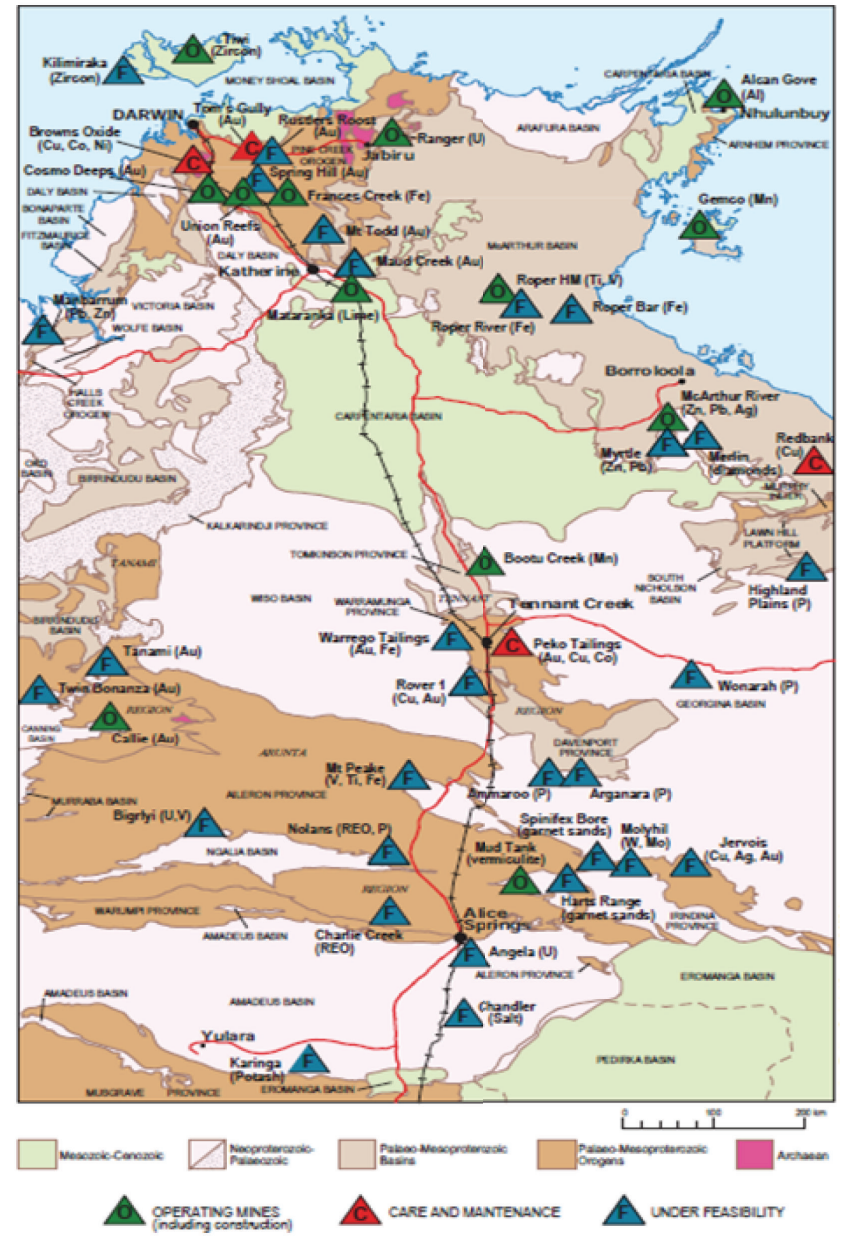

Figure 5: The mineral sites map for the NT [46].

trough plants. The investment costs of CSP plants differ from a region to another depending on solar intensity and its uniformity in that region. A region with less uniform and low amount of solar irradiation will require higher solar multiple and, hence, larger solar collector field. Similarly, the maintenance/operating costs are higher for a low solar irradiation area, as they consume higher amount of backup fuel for producing power.

Considering the cost breakdown presented in the literature $[28,39]$, heliostats are more economically attractive compared to trough systems, and the initial cost of installing a thermal storage system for central tower is almost half of the initial cost for installing a thermal storage system for trough system. However, there are additional costs associated with tower and receiver construction for tower plants.

In the context of mining operations in the NT, installation of CSP plants could be economically viable. Although individual mines (power requirement in the order of $20 \mathrm{MW}$ $[44,45])$ may not have sufficient demand for power to sustain their own plants, mine clusters can be identified which would underpin the cost effectiveness (see Section 3.3). 


\section{Results and Discussion}

4.1. NT Mining Operations. There are at least 76 mining operations in the NT of which 28 are operating, 8 care and maintenance mines, and 40 feasibility mines (as of June 2013) [46]. In the NT context, the crucial factors identified in Section 3 combined with the data provided in [46] lead to the following observations.

A minimum economic life time of an application is the first and possibly the major parameter that decides whether a CSP plant will be economically viable or other (renewable) energy system options should be considered for power production. Majority of the mines (Figure 5) in the NT have sufficient lifespan to sustain CSP applications. Initial estimations of the lifespan for many were in the order of 10-15 years' lifespan; however in most cases this has been extended to 25 years and beyond as the new and improved exploration and production technologies became available. For example, the Bootu Creek mine [47, 48] producing manganese has been operating between 1955 and 1963 and has been abandoned for decades after. However, it reopened in 2005 and in 2009 its expected lifespan has been further extended by over 13 years. McArthur River Mine has been in operation since 1995 and the initial estimated lifespan was in the order of 25 years [49]. In 2013, this period was extended by a further 11 years.

4.2. Temperature and Power Requirements. Most of the onsite treatment in mining industry is limited to crushing and leaching which do not involve extremely high temperatures [50]. For example, gold extraction process rarely encounters temperatures higher than about $100^{\circ} \mathrm{C}$ [51]. However, high temperature roasting, up to $980^{\circ} \mathrm{C}$ according to some sources [52-54], is often employed at uranium and bauxite/Al processing facilities. An appropriate CSP technology can therefore be identified from Table 1.

When considering the type of the load (peak load versus base load) and the required size of the power plant, it becomes obvious that many mines will not be able to sustain a CSP plant of their own. For example, zinc and lead production at McArthur River Mine requires 45-50 MW [55]. Tanami gold operations consume $30 \mathrm{MW}$ and the nearby granites gold mine requires a further $40 \mathrm{MW}$ capacity [56]. It is worth mentioning that currently the power can be supplied to these mines from at least 3 independent sources: power grid, diesel, and the nearby gas pipeline; however diesel is by far the major source of energy. However, the mining sites tend to form regional clusters (Figure 5), and CSP technology seems to be a convenient solution to provide power to particular regions. These are Darwin-Katherine region which is also called Pine Creek area, the Tennant Creek area, and the Alice Springs region. There are also few mining operations in the central-west area of the NT, known as Tanami region, in the east of the NT in McArthur River region, and few individual mining operations at Jabiru and Tiwi Islands. Nhulunbuy sites were considered in this study initially, but the results are not presented here due to the announcement made by Rio Tinto to cease operations in this region.
4.3. Environmental Considerations. Interestingly, these mine clusters also sit within particular climatic areas: tropical/coastal (McArthur River Mine), monsoonal (Ranger Mine), tropical/inland (Northern Territory Gold Mines), and arid/desert climates (Tanami Operations). Each of these is characterised by a particular set of atmospheric conditions such as DNI, average cloud cover, and susceptibility to severe weather including strong winds and flooding. In accordance with the data discussed in the previous section, preliminary analysis of feasibility of CSP installation can be conducted. The DNI maps provided in the previous section indicate that the average DNI in all regions is $2200-2800 \mathrm{kWh} / \mathrm{m}^{2}$ which is sufficiently higher than that required for a CSP plant. Only the tropical coastal areas fall under the requirement for cycloneproof structures; however, being sufficiently far from the coast (at least $70 \mathrm{~km}$ ) the winds rarely exceed $20 \mathrm{~km} / \mathrm{hr}$, and therefore associated risks are relatively low. This region also has the highest rainfall; however, the existing infrastructure allows for uninterrupted operation of the mine in terms of road communication. Desert environment is on the other end of extremes, and the available water resources are extremely scarce. However, most of SCP installations exist in similar environments and utilise dry cooling as discussed in the previous section.

This preliminary evaluation suggests that four CSP plants could be constructed to cater for the needs of mining operations and local communities in each of the four areas identified above. However, a more thorough study will have to be conducted in order to investigate the details of each of these installations such as to provide an insight into the best suitable CSP technology and possible complications. This will form the scope for a future research where a simple algorithm will be developed for quick assessment of feasibility of CSP in each location.

\section{Conclusion}

The potential application of concentrated solar power for remote mine sites in the Northern Territory has been discussed. The following are the main conclusions.

(i) NT mining sector represents the largest electricity consumer within the unregulated network as well as on a territory level and is among NT's biggest consumers of fossil fuels with significant GHG emissions.

(ii) Renewable energy share in the NT electricity generation is still quite low at $0.65 \%$ with solar as the major contributor. As such, solar energy, which is abundant in the NT, can play an important role in reducing the reliance on fossil fuels in the mining sector.

(iii) Based on the CSP's main feasibility parameters, the study recommended that CSP plant installation be considered at the regional cluster level rather than at individual mine sites.

(iv) The following clusters have been identified for potential CSP plant installation: McArthur River Mine, Ranger Mine, Northern Territory Gold Mines, and Tanami Operations. The CPS plant installed at each 
cluster should serve to provide power to the mining operation and the local communities.

(v) A more thorough study will have to be conducted in order to investigate the details of each of these installations so as to provide an insight into the most suitable CSP technology and likely implications. This will form the scope for a future research.

\section{Conflict of Interests}

The authors declare that there is no conflict of interests regarding the publication of this paper.

\section{References}

[1] K. Lovegrove, M. Watt, R. Passey, G. Pollock, J. Wyder, and J. Dowse, Realising the Potential of Concentrating Solar Power in Australia, IT Power Australia, Australian Solar Institute, Canberra, Australia, 2012.

[2] Australian Government, Department of Industry, Innovation, Climate Change, Science, Research and Tertiary Education, Quarterly Update of Australia's National Greenhouse Gas Inventory, Australian National Greenhouse Accounts, 2012.

[3] Carbon Neutral website, Australia's Greenhouse Gas Emissions, 2013, http://www.carbonneutral.com.au/climate-change/australianemissions.html.

[4] WWF website, "Where do Australia's greenhouse gases come from?” 2014, http://www.wwf.org.au/our_work/people_and_the environment/global_warming_and_climate_change/science/ australia_greenhouse_gases/.

[5] N. Che, A. Feng, C. McCluskey, P. Pham, T. Willcock, and G. Stanwix, 2013 Australian Energy Update, Bureau of Resources and Energy Economics, Australian Government, Canberra, Australia, 2013, http://bree.gov.au/.

[6] The Northern Territory Government Green Energy Task Force, "An evaluation of the relative merits, feasibility, and likely costs of the potentially available renewable energy technologies to be used in the NT, including geo-thermal, solar, biomass and tidal," Tech. Rep. 2, The Northern Territory Government Green Energy Task Force, 2010.

[7] Energy White Paper 2012, Australia's Energy Transformation, Department of Resources, Energy and Tourism, 2012.

[8] Northern Territory Government, "Appendix A-strategic overview of the northern Territory's energy landscape," Draft Energy White Paper, Northern Territory Government, 2012.

[9] ARENA, "Weipa 6.7MW solar photovoltaic (PV) solar farmAustralian Renewable Energy Agency (ARENA)," 2014, http:// arena.gov.au/project/weipa-solar-farm/.

[10] ARENA, "ASTRI: Australian Solar Thermal Research Initiative," Australian Renewable Energy Agency (ARENA) website, 2012, http://arena.gov.au/project/astri-australian-solar-thermal-research -initiative/.

[11] J. Clifton and B. J. Boruff, Concentrating Solar Power-Global Outlook 2009-Why Renewable Energy is Hot, Greenpeace International, SolarPACES and ESTELA, 2009, http://www .estelasolar.eu/fileadmin/ESTELAdocs/documents/Greenpeace_ Concentrating_Solar_Power_2009.pdf.

[12] J. Clifton and B. J. Boruff, Renewable Energy Technologies: Cost Analysis Series-Vol. 1: Power Sector Issue 2/5-Concentrating Solar Power, International Renewable Energy Agency, 2012, http://www.irena.org/DocumentDownloads/Publications/RE_ Technologies_Cost_Analysis-CSP.pdf.
[13] CSP World website, 2015, http://www.csp-world.com/resources/ technology.

[14] S. A. Kalogirou, Solar Energy Engineering: Processes and Systems, Elsevier Science, 2009.

[15] SolarPACES Website, 2014, http://www.solarpaces.org/csp-technology.

[16] W. Vogel and H. Kalb, Large-Scale Solar Thermal Power: Technologies, Costs and Development, Wiley-VCH, 2010.

[17] J. Clifton and B. J. Boruff, "Assessing the potential for concentrated solar power development in rural Australia," Energy Policy, vol. 38, no. 9, pp. 5272-5280, 2010.

[18] M. S. Al-Soud and E. S. Hrayshat, "A 50 MW concentrating solar power plant for Jordan," Journal of Cleaner Production, vol. 17, no. 6, pp. 625-635, 2009.

[19] IEA website, Technology Roadmap Concentrating Solar Power, International Energy Agency, 2010, http://www.iea.org.

[20] IEA, Concentrating Solar Power Projects under Construction, NREL, 2013, http://www.nrel.gov/csp/solarpaces/projects_by_ status.cfm? status=Under\%20Construction.

[21] O. Behar, A. Khellaf, and K. Mohammedi, "A review of studies on central receiver solar thermal power plants," Renewable \& Sustainable Energy Reviews, vol. 23, pp. 12-39, 2013.

[22] S. Kaneff, The White Cliffs Project Overview for the Period 197989, Office of Energy, Sydney, Australia, 1991.

[23] S. Kaneff, Solar Energy 10, Australian Bureau of Agricultural and Resource Economics (ABARE), Canberra, Australia, 2010, http://arena.gov.au/files/2013/08/Chapter-10-Solar-Energy.pdf.

[24] CSIRO Website, "Australian solar thermal research initiative," 2013, http://www.csiro.au/en/Research/EF/Areas/Solar/Solarthermal/ASTRI.

[25] S. Blanch, R. Law, A. Campbell, E. Halawa, and C. Eiritz, Scoping Workshop on Australia-South East Asia Grid Connection to Catalyse Regional Generation and Distribution of Renewable Energy, 29-30 July 2013, Environment Centre NT \& Centre for Renewable Energy, Charles Darwin University, Casuarina, Australia, 2013.

[26] K. Ravi Kumar and K. S. Reddy, “4-E (energy-exergy-environmental-economic) analyses of line-focusing stand-alone concentrating solar power plants," International Journal of LowCarbon Technologies, vol. 7, no. 2, pp. 82-96, 2012.

[27] G. Cau, D. Cocco, and V. Tola, "Performance and cost assessment of Integrated Solar Combined Cycle Systems (ISCCSs) using $\mathrm{CO}_{2}$ as heat transfer fluid," Solar Energy, vol. 86, no. 10, pp. 2975-2985, 2012.

[28] G. M. Masters, Renewable and Efficient Electric Power Systems, John Wiley \& Sons, Hoboken, NJ, USA, 2013.

[29] Y. Zhang, S. J. Smith, G. P. Kyle, and P. W. Stackhouse, "Modeling the potential for thermal concentrating solar power technologies," Energy Policy, vol. 38, no. 12, pp. 7884-7897, 2010.

[30] I. Craig, D. Thorpe, F. Kamel, and S. Goh, "Concentrating solar power: parabolic trough with $20 \%$ gas boost (CSP-PT+20\%)," in Proceedings of the Southern Region Engineering Conference (SREC '10), Toowoomba, Australia, 2010, http://eprints.usq.edu .au/18253/.

[31] S. Janjai, J. Laksanaboonsong, and T. Seesaard, "Potential application of concentrating solar power systems for the generation of electricity in Thailand," Applied Energy, vol. 88, no. 12, pp. 4960-4967, 2011.

[32] K. Kaygusuz, "Prospect of concentrating solar power in Turkey: the sustainable future," Renewable and Sustainable Energy Reviews, vol. 15, no. 1, pp. 808-814, 2011. 
[33] SolarGIS website, "Golbal Horizontal Irradiation Australia," 2013, http://solargis.info/doc/_pics/freemaps/1000px/ghi/SolarGISSolar-map-Australia-en.png.

[34] Geoscience Australia and ABARE, Australian Energy Resource Assessment, Geoscience Australia and ABARE, Canberra, Australia, 2010.

[35] L. B. Hutley, B. J. Evans, J. Beringer, G. D. Cook, S. W. Maier, and E. Razon, "Impacts of an extreme cyclone event on landscapescale savanna fire, productivity and greenhouse gas emissions," Environmental Research Letters, vol. 8, no. 4, Article ID 045023, 2013.

[36] T. M. Pavlović, I. S. Radonjić, D. D. Milosavljević, and L. S. Pantić, "A review of concentrating solar power plants in the world and their potential use in Serbia," Renewable \& Sustainable Energy Reviews, vol. 16, no. 6, pp. 3891-3902, 2012.

[37] Y. Kuleshov, R. Fawcett, L. Qi et al., "Trends in tropical cyclones in the South Indian Ocean and the South Pacific Ocean," Journal of Geophysical Research D: Atmospheres, vol. 115, no. 1, 2010.

[38] ABCB Regulation impact statement for final decision-the Australian Building Codes Board, 2012.

[39] J. T. Hinkley, J. A. Hayward, B. Curtin et al., "An analysis of the costs and opportunities for concentrating solar power in Australia," Renewable Energy, vol. 57, pp. 653-661, 2013.

[40] MACCSol Project, http://www.drycooledcsp.eu/.

[41] Vast Solar website, "Vast Solar's 6MWth Facility with thermal energy storage - the 'Jemalong Solar Thermal Station,"' April 2015, http://www.vastsolar.com/community/project-updates/ 82-jemalong-thermal-solar-station-project-update-may-2014.

[42] S. J. Gale, "Long-term landscape evolution in Australia," Earth Surface Processes \& Landforms, vol. 17, no. 4, pp. 323-343, 1992.

[43] Aboriginal Land Rights (Northern Territory) Regulations 2007Select Legislative Instrument no. 184, 2007 as amended-made under the Aboriginal Land Rights (Northern Territory) Act 1976.

[44] PWC, Annual Report, Power and Water Corporation, Darwin, Australia, 2011, http://www.powerwater.com.au/__data/assets/ pdf_file/0017/38600/Power_and_Water_Annual_Report_2011_-_ Revised.PDF.

[45] PWC 2012, Annual Report, Power and Water Corporation, Australia, April 2015, http://www.powerwater.com.au/__data/ assets/pdf_file/0005/49658/PW_AR_Snapshot_2012_web.pdf.

[46] PWC, "NT Government CORE official website," 2012, COREhttp://www.core.nt.gov.au/minesdevprojects.html.

[47] OM Holdings Ltd, April 2015, http://www.omholdingsltd.com/ subsidiary_omm.htm.

[48] N. H. Scriven and T. J. Munson, "Manganese in the sand and spinifex, Bootu Creek area, Northern Territory," April 2015, http://www.nt.gov.au/d/Minerals_Energy/Geoscience/Cabs/ papers/P49_Scriven_Munson.pdf.

[49] McArthur River Mining-Phase 3 development project, April 2015, http://www.mcarthurrivermine.com.au/EN/mineexpansion/Pages/Phase3DevelopmentProject.aspx.

[50] Access Engineering Library-Manufacture of Chemicals, April 2015, http://accessengineeringlibrary.com.ezproxy.cdu.edu.au/ browse/chemical-process-and-design-handbook/p2000a9a199702_ 1001 .

[51] J. Marsden and C. I. House, Chemistry of Gold Extraction, Society for Mining, Metallurgy \& Exploration, Englewood Cliffs, NJ, USA, 2006.

[52] B. Weil, "Uranium Mining and Extraction from Ore," 2012, http://large.stanford.edu/courses/2012/ph241/weil2/.

[53] D. Donaldson and B. Raahauge, Essential Readings in Light Metals, Alumina and Bauxite, John Wiley \& Sons, 2013.
[54] N. W. Hanf and C. G. Schmidt, "The roasting and leaching of Witwatersrand pyrite concentrates," Journal of the the Southern African Institute of Mining and Metallurgy, pp. 365-371, 1979.

[55] McArthur River Mining, "Sustainability Reports 2013," April 2015, http://www.mcarthurrivermine.com.au/EN/Publications/ Pages/default.aspx.

[56] Newmont website, 2014, http://www.newmont.com/operationsand-projects/australia-pacific/default.aspx. 


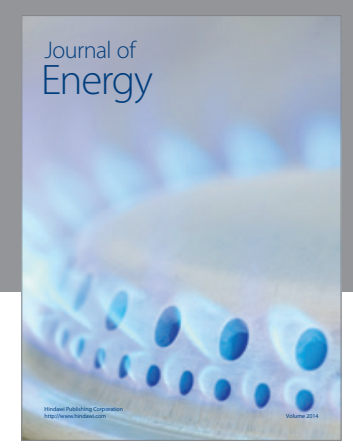

Journal of

Industrial Engineering
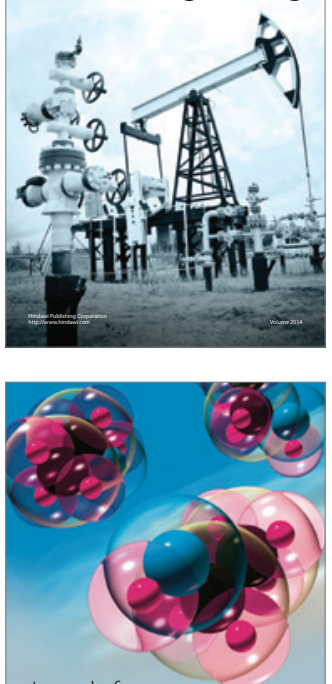

Fuels
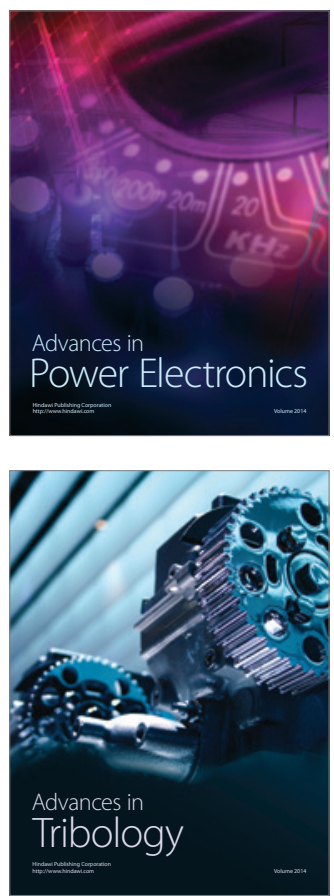

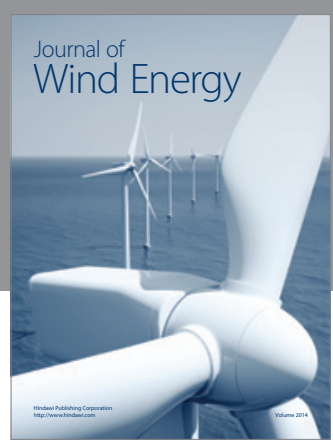

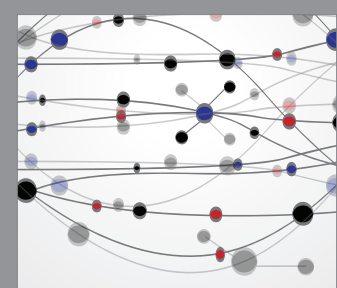

The Scientific World Journal

Submit your manuscripts at http://www.hindawi.com

Journal of

Structures
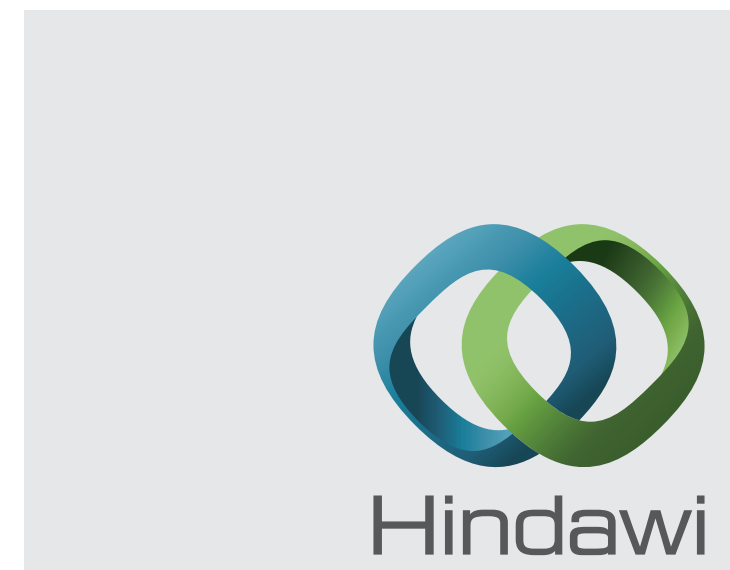

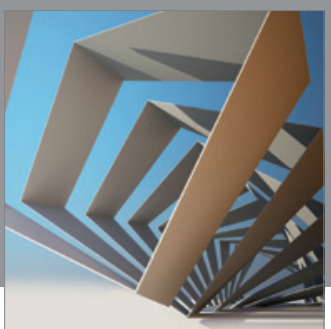

Rotating

Machinery
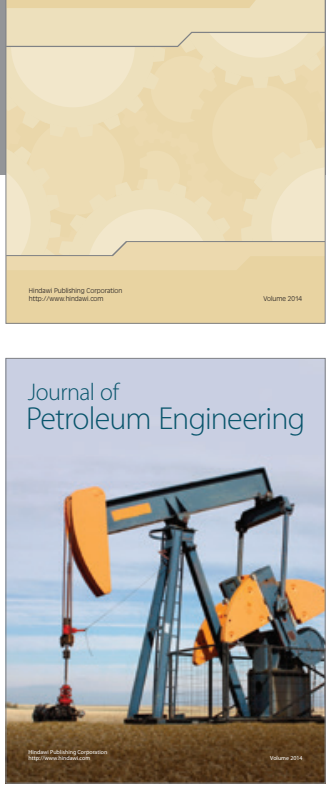

Journal of

Solar Energy
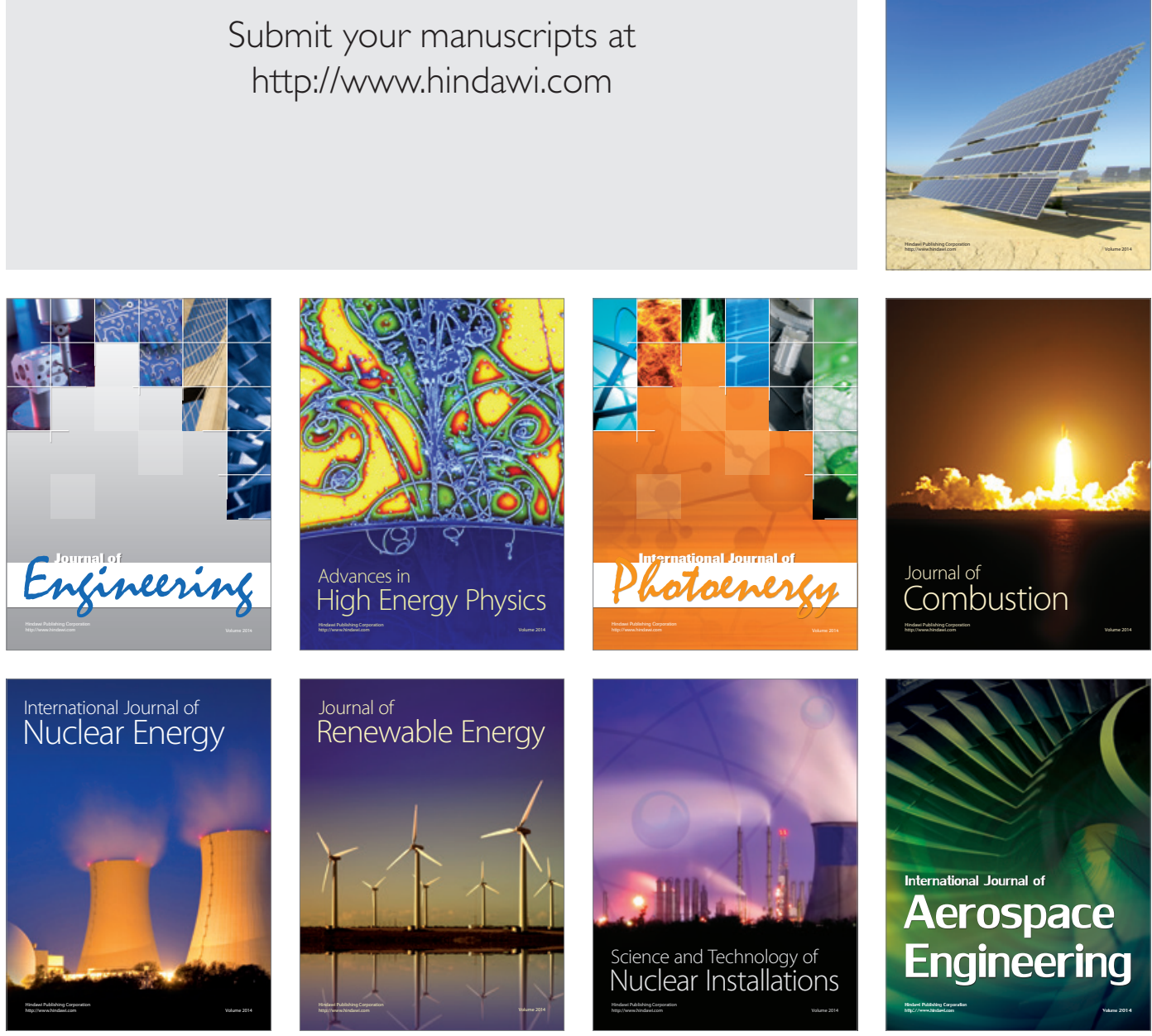